\title{
Pattern of Pro-Isis Terrorist Financing In Indonesia: Study About The Santoso Group
}

\author{
Prihandoko $^{1}$, Muhamad Syauqillah ${ }^{2}$ \\ \{prihandoko@ui.ac.id ${ }^{1}$, muhamadsyauqillah@ui.ac.id² \\ Universitas Indonesia, Jakarta, Indonesia
}

\begin{abstract}
This study investigates the funding pattern of the Mujahidin Indonesia Timur (MIT) or the Santoso Group, one of the terrorist groups in Indonesia which pledges allegiance to the Islamic State of Iraq and Syria (ISIS). The purpose of this study was to explain the strategy of the Santoso Group in collecting and managing donations from sympathizers to support their terror activities in the Poso region, Central Sulawesi. This study uses a qualitative method. The primary data is obtained from in-depth interviews with two former members of the Santoso Group, the Supreme Court's decision document on one of member of the Santoso Group, and the National Agency for Counter Terrorism (BNPT) documents on terrorism funding related to ISIS-affiliated domestic terrorist networks. The secondary data comes from interviews with a member of the BNPT Terrorism Funding Control Team and a member of the Indonesian National Anti-Terrorism Special Detachment 88 (Densus 88/Detachment 88). The analysis in this study uses The Rational Choice Theory of Martha Crenshaw about the logical thinking of terrorists. The results of the study show that the Santoso Group has a number of members who are specifically tasked to collect and manage donation donors by utilizing e-mail services and a number of social medias. The strategy of collecting and managing the donations was used by Santoso Group because it was considered the safest and easiest way.
\end{abstract}

Keywords: Terrorist Financing, Santoso Group, Mujahidin Indonesia Timur, Poso.

\section{Introduction}

The Islamic State of Iraq and Syria (ISIS) is a terrorist organization or group that has become a threat to world security in recent years. Even though the main base is in Iraq and Syria, but ISIS's radicalism propaganda get support from sympathizers and terrorist networks in other countries. Sympathizers and terrorist networks in a number of these countries even claim to be affiliated with ISIS--or called allegiance to ISIS.

In Indonesia, support for ISIS was first delivered by a radical group of Forum Aktivis Syariat Islam (FAKSI) in March 2014. After that, support for ISIS continued to emerge. The increased support is inseparable from the role of Tuah Febriwansyah aka Muhammad Fachry (IPAC Report, 2014, p. 2). In 2005, Fachry was inspired by the doctrine of a Syrian cleric, Omar Bakri Muhammad. Omar Bakri, along with Anjem Choudary, was the founder of AlMuhajiroun, a jihadist salafi organization which was the wing of the Hizbut Tahrir. In his doctrine, Omar Bakri said that the Islamic Caliphate could be built--if necessary by using force- 
-through the establishment of a territorial zone called the "Imarah Islam". Fachry and some of his friends intend to establish the territorial zone in Indonesia (Jones and Solahudin, 2015, p. 155).

On June 29, 2014, ISIS declared the establishment of the Caliphate under the name Ad Daulah Al Islamiyyah that lead by Abu Bakar Al-Baghdadi. They claim their territory covers Aleppo, Syria, to Diyala, Iraq. Fachry took part in supporting the Caliphate after finding out that Omar Bakri declared allegiance to ISIS. Fachry and several people inspired by Omar Bakri and Choudary then became pro-ISIS network machines in Indonesia (IPAC Report, 2014, p. 1). They manage the site www.al-mustaqbal.net as an ISIS propaganda platform.

The declaration of the ISIS Caliphate was welcomed by the support of a number of people suspected of being linked to acts of terrorism in Indonesia. On June 30, 2014, Aman Abdurrahman--now known as the Amir of Jamaah Ansharut Daulah (JAD)--expressed his allegiance to ISIS (IPAC Report, 2014, p. 15). At that time, Aman was serving a 9-years sentence at the Nusakambangan Penitentiary, Cilacap, Central Java. Aman, who is an Arabic linguist, has been known as a translator of ISIS since November 2013 and has been featured on a number of radical sites, including www.al-mustaqbal.net (Jones and Solahudin, 2015, p. 156).

On July 5, 2014, several terrorism suspects in the detention center Mako Brimob, Kelapa Dua, Depok, West Java, took an oath of allegiance to ISIS (IPAC Report, 2014, p. 15). The Amir of the Jamaah Ansharut Tauhid (JAT), Abu Bakar Baasyir, on July 14, 2014 also supported ISIS, which then triggered the division of his group into Jamaah Ansharut Daulah (JAD)/supporters of Baasyir and Jamaah Ansharut Shariah (JAS)/opponent Baasyir. After that, hundreds of other people in a number of places also pledged to support ISIS, including in Malang, East Java; Solo, Central Java; Makassar, South Sulawesi; Mukomuko, Bengkulu; Lampung; and East Kalimantan. Until the end of August 2014, an estimated 2,000 Indonesians expressed their allegiance to ISIS (IPAC Report, 2014, p. 16).

Some radical Islamic organizations or groups related to acts of terrorism in Indonesia also swore allegiance to ISIS. They include the Tauhid Wal Jihad (TWJ), the Ring Banten Group, Mujahidin Indonesia Barat (MIB), and Mujahidin Indonesia Timur (MIT). Of all, MIT, also known as the Santoso Group, became the first radical Islamic organization or group in Indonesia to openly declare allegiance to ISIS after the declaration of the Caliphate of the Ad Daulah Al Islamiyyah (Jones and Solahudin, 2015, p. 154). They supported ISIS in July 2014 through videos uploaded on Youtube.

MIT is a radical Islamic group that often carries out acts of terror in the Poso region, Central Sulawesi. The formation of this group begins from the ambition of the Jemaah Islamiyah (JI) radical group network to establish an Islamic state in Poso. The idea was discussed by a former JI frontman and JAT administrator, Abu Tholut, along with Santoso alias Abu Wardah and Sutomo bin Sudarto aka Mohammad Yasin aka Ustaz Yasin in 2009. They then agreed on the initial steps to prepare qoidah aminah--the base area for the Islamic state--in Poso is to conduct military training to create cadres who will fight for an Islamic state (Mbai, 2014, p. 30-31).

In addition, Abu Tholut also proposed that JAT be formed immediately in Poso, with Santoso as the head of asykariy (military training section) and Ustaz Yasin as the organization's ambassador. The formation of the JAT in Poso was considered important because it was the forerunner of the Islamic government there. To realize the plan, Santoso and his friends began collecting weapons and looking for military training sites. In 2010, they managed to buy several weapons and found military training sites in the areas of Gunung Mauro, Tambarana, Poso Pesisir, and the area of Gunung Biru, Tamanjeka, Poso Pesisir (Mbai, 2014, p. 31). 
Santoso and his friends got opportunity to realize their plans after the radical group, Lintas Tanzim Aceh failed to make Aceh as qoidah aminah in 2010. Lintas Tanzim Aceh was an alliance of various jihad groups in Indonesia, including JAT, Ring Banten Group, Mujahidin KOMPAK, and Tauhid Wal Jihad. At that time, their military training camp in Jantho, Aceh Besar, caught by the police. Dozens of people were arrested, including Abu Bakar Baasyir, who was involved in funding the training (Mbai, 2014, p. 24-26). This condition makes Poso the right substitute for forming qoidah aminah. Moreover, the JI network, through Abu Tholut, had previously planned to form the basis of the origin of the Islamic state in Poso (Jones and Solahudin, 2014, p. 139-140).

To pioneer the formation of JAT Poso, Santoso and Ustaz Yasin began recruiting a number of people to join. In January 2011, JAT prospective members reached around 50 people. After the number of members was considered sufficient, Santoso and Ustaz Yasin arranged the management of JAT Poso. In September 2011, JAT Poso was officially formed, with Ustaz Yasin as his Amir and Santoso as the ashkariy leader. After that, JAT Poso continued to hold military training which was also attended by people from outside Poso. The weapons they use are obtained in various ways. One of them seized from the police. Not only robbing them, they are also encouraged to kill the police (Mbai, 2014, p. 32-34).

For JAT Poso, the police are number one enemy. The reason is that the police have arrested and killed their friends who tried to form qoidah aminah in Aceh (Jones and Solahudin, 2014, p. 139-140). On that basis, JAT Poso often carried out a number of acts of terror that targeted the police, such as shooting police, kidnapping and killing police, ambushing police patrol cars, or detonating bombs in front of the police station. These actions made those who joined the Poso JAT become police targets, including Santoso.

Later, JAT Poso changed its name to Mujahidin Indonesia Timur (MIT) with Santoso as its leader. Because it was the target of the police, their movement narrowed until they finally chose the Gunung Biru area, Tamanjeka, Poso Pesisir, as their base and citadel from the police. The Indonesian Anti-Terrorism Special Detachment 88 (Densus 88/Detachment 88) noted, at first there were around 40-45 members of the Santoso Group who guerrilla in the Gunung Biru area (Interview with a member of Densus 88, 2018). This figure includes additional personel from the Abu Autad Rawa group aka Daeng Koro group who joined the Santoso Group in 2013. Daeng Koro is a figure of the South Sulawesi Darul Islam who had helped JI people against the police during the Tanah Runtuh incident in Poso in 2007 (Mbai, 2014, p. 46).

In fact, among the Santoso Group members on the mountain, there is also Foreign Terrorist Fighters (FTF) from the Uighur Tribe, China. Densus 88 noted that there were 6 Uighur FTF members who joined the Santoso Group on the mountain--who were later arrested--and 5 others were arrested when entering Poso (Interview with a member of Densus 88, 2018). Apart from that, Santoso Group also received support from sympathizers in Poso and jihadist networks in a number of cities, including North Sumatra, South Sulawesi, East Kalimantan, West Nusa Tenggara, and all of Java (Jones and Solahudin, 2014, p. 140).

To combat the Santoso Group, in 2015 Polri with TNI held Camar Maleo Operation, which later changed its name to Tinombala Operation. The operation succeeded in capturing and killing a number of group personnel, including Santoso who was shot dead in July 2016. Even so, until now the Santoso Group still exists in the Gunung Biru area, Poso. Densus 88 noted that there were about 10 group personnel who were still on the mountain. They moved from one place to another under the coordination of Ali Kalora, the person who was mentioned as Santoso's right hand (Interview with a member of Densus 88, 2018). 
Since it was formed, the Santoso Group cannot carry out their various activities, including carrying acts of terror, without funding support. There were three sources of funding that supported the Santoso Group as long as they stood, namely the infak of members, robbery of motorbikes or called $f a^{\prime} i$, and donations from sympathizers. The three sources of funds became their mainstay in 2011-2014. Afterwards, including when the Santoso Group expressed their allegiance to ISIS, they only relied on donations from sympathizers as the main source of funding. This research will explain the funding pattern of the Santoso Group, especially the group's strategy in collecting and managing donations from sympathizers to support their terror activities in the Poso region.

\section{Methods}

In 1999, The International Convention for the Suppression of the Financing of Terrorism in defines terrorism funding as an act of crime committed by someone directly or indirectly, legally or illegally, in the form of giving or collecting funds for the purpose of being used or will be used in full or in part, to carry out acts of terrorism (Hamin, et. al., 2016, p. 399). The definition of terrorism funding is a benchmark for all countries in the world, including Indonesia.

In Indonesia, an explanation of terrorism funding is contained in Law Number 9 of 2013 about Prevention and Eradication of Crime in the Financing of Terrorism. Article 1 of the law states that terrorism funding is all acts in the context of providing, collecting, giving, or lending funds, directly or indirectly, with the intention of being used and/or known to be used for terrorism activities, terrorist organizations or terrorist. The act can be done individually or as a corporation or group of people.

All acts of terrorism require funding. Money or funds is needed to carry out acts of terrorism, not as a goal to be sought. Therefore, various ways will be carried out by terrorists to obtain funds legally or illegally. Efforts to obtain funds legally such as the business of buying and selling cell phone pulses, asking for donations, selling computer equipment, selling herbal medicines, or opening an Internet shop. While unauthorized methods are carried out through acts of crime such as robbery, fraud, and hacking online investment sites (Indonesian National Risk Assessment Team, 2015, p. 8).

For a terrorist organization or group, funding can be used to pay five things. First, for operational needs, for example food costs, transportation to and from locations of terror targets, buying weapons or explosives, and falsifying personal identity documents. Second, for propaganda and recruitment. In addition to multiplying members, propaganda and recruitment are also intended to seek additional funds. In that effort, terrorist organizations or groups often use the Internet, such as creating website pages or through social media. Third, for training members or sympathizers. The costs include the provision of training locations and all facilities. Fourth, for the salary or wages of leaders and members, as well as contributions to families of members who were killed or captured. Fifth, for social donations. In this case, many terrorist organizations or groups allocate their funds to establish or donate to social institutions that provide health, social and educational services. The aim is to seek public support and undermine the legitimate credibility of the government (FATF, 2015, p. 9-10).

Funding for terrorist organizations or groups can come from a number of sources: personal contributions from sympathizers or network groups; abuse of authority or misappropriation of funds in a non-profit organization or foundation; commit criminal acts such as robbing banks, 
selling narcotics, and credit card fraud mode; exporting goods or doing business; kidnap to get ransom; profits from the company they founded; and donations from countries that sympathize with the terrorist group. (FATF, 2015, p. 13-20). The source of funding can vary within each terrorist organization or group. Jemaah Islamiyah (JI), for example, did a lot of robbery or $f a^{\prime} i$ to finance their terror activities. While the group that supports JI like Al-Qaeda, doing criminal acts to raise funds, such as selling narcotics (Balasubramaniya, 2015, p. 478-480).

In the beginning, terrorist organizations or groups used very "traditional" methods of transferring funds, such as through bank transfers, currency exchange systems, and cash transfers (FATF, 2015, p. 20-23). However, along with the development of technology, the way of transferring funds used by terrorist organizations or groups has also become more sophisticated, for example using virtual currency, prepaid bank cards, and Internet-based payment or transfer services (FATF, 2015, p. 35-38).

The Indonesian National Risk Assessment (NRA) Team has identified the riskiest mode of terrorism funding in Indonesia in 2011-2014. The team members come from several institutions that handle terrorism funding in Indonesia such as Densus 88, the Indonesian Attorney General's Office on Terrorism Task Force, the Supreme Court of Indonesia, the High Court/District Court, the Badan Nasional Penanggulangan Terorisme/National Counter Terrorism Agency (BNPT), and Pusat Pelaporan dan Analisis Transaksi Keuangan/Financial Transaction Reports and Analysis Center (PPATK).

The identification results show the five most risky modes of terrorism funding in Indonesia in 2011-2014. First, domestic funding through cash donation to a foundation used to manage terrorist networks. Second, domestic funding through misuse of foundation funds using cash instruments used to manage terrorist networks. Third, domestic funding through trading/business (goods/services) using cash instruments used to manage terrorist networks. Fourth, domestic funding through criminal acts using cash instruments used to manage terrorist networks. Fifth, domestic funding through misuse of foundation funds to open new business activities (goods/services) which results in managing terrorist networks (Indonesian National Risk Assessment Team, 2015, p. 22). If summarized, the terrorism funding mode becomes as follows:

Table 1. Terrorism Funding Mode in Indonesia in 2011-2014

\begin{tabular}{llll}
\hline Source of Funds & Sources of funding & $\begin{array}{l}\text { Transaction } \\
\text { Instrument }\end{array}$ & Funding Purpose \\
\hline Domestic & $\begin{array}{l}\text { 1. Donation } \\
\text { 2. Misuse of foundation } \\
\text { funds }\end{array}$ & Use cash & $\begin{array}{l}\text { Managing terrorist } \\
\text { networks }\end{array}$ \\
& $\begin{array}{l}\text { 3. Business activities } \\
\text { 4. Criminal act (for } \\
\text { example robbery) }\end{array}$ & \\
\hline
\end{tabular}

Source: Indonesian National Risk Assessment Team. (2015). Indonesian Risk Assessment of Terrorism Funding Crime in 2015, p. 23.

In 2011-2014, the NRA team also identified a number of ways to transfer funds related to terrorism, namely through electronic payment systems or using cards like ATM cards, credit 
cards, and shopping cards; through online payment systems, such as Internet banking and mobile banking; through a new payment system (New Payment Method), for example virtual currency and virtual accounts; through the carrying of cash or similar instruments in the country; through carrying cash or similar instruments across national borders (cash smuggling); through legal business or business activities that are already underway or opening new business activities; through jewelry and precious metal traders; through motorized vehicle traders; and through money changer (National Risk Assessment Indonesia Team, 2015, p. 30-31).

Freeman (2012) in Hamin, et. al. (2014) mentions six criteria that are often considered by terrorist organizations or groups in determining funding methods, namely quantity, legitimacy, security, reliability, control, and simplicity. In terms of quantity, terrorist organizations or groups clearly want the largest source of funding. With a lot of funds, they can carry out terror attacks more often and on a larger scale. In addition, large amounts of funds can also make terrorist organizations or groups more powerful and effective. While legitimacy, needed to support the existence of the terrorist organizations or groups. With legitimacy, they will also obtain legitimate recognition from the state so that they do not need to look for specific funding sources, so they cannot be detected (p. 401).

For security criteria, terrorist organizations or groups will choose funding sources that can predict the risks and stability. It is important to determine the level of security of the funding source. While about reliability, terrorist organizations or groups will avoid donations from external sponsors, such as the state or donors from private parties, because it can influence the group's decision to do or not do something. The control of funding is needed by terrorist organizations or groups so that they do not fail in carrying out acts of terror. In addition, they also need control over the time and speed of their funding, especially if they need fast funds to carry out terror attacks. While simplicity of funding is clearly needed by every terrorist organization or group. The reason is that a simple or simple funding method does not require special expertise, the process is simple, and the cost to run it is also cheaper. For example, theft or extortion that is easier to do than cyber crime (Hamin, et. Al., 2014, p. 401).

Referring to the report of the Financial Action Task Force (2015) and the results of the identification of the Indonesian National Risk Assessment Team (2015), this study will explain the source or mode of funding and the way of transferring funds applied by the Mujahidin Indonesia Timur (MIT) or Santoso Group, especially after they declared allegiance to the Islamic State of Iraq and Syria (ISIS) in 2014. To reveal the funding pattern of the group, this study used qualitative methods. The primary data used were the results of in-depth interviews with two former Santoso Group members: Gunawan Djuraedjo aka Gugun aka Agus aka Ninja and Muhammad Fadli Gani Ibrahim aka Rodik aka Mamat. Interviews were conducted in Poso Kota and Tentena, Poso District, Central Sulawesi, on 29-30 August 2018.

Other primary data used are document of the Republic of Indonesia's Supreme Court's decision on one of member of the Santoso Group, namely Ramadhan Ulhaq aka Deni (Decision Number 775/Pid.Sus/2015/PN.JktTim) and the BNPT White Paper document in 2017 on Mapping the Risk of Terrorism Funding Crimes related to the Domestic Terrorist Network Affiliated with the Islamic State of Iraq and Syria (ISIS). The secondary data used in this study are the results of in-depth interviews with a member of the BNPT Terrorism Funding Control Team and a member of Densus 88. Interviews with a member of the BNPT Terrorism Financing Team were conducted in Serpong, South Tangerang, Banten on July 16, 2018, while interviewing a member of Densus 88 was conducted in Jakarta on 2 August 2018.

To analyze the strategy of the Santoso Group in collecting and managing funding, this study uses The Rational Choice Theory proposed by Martha Crenshaw in 1998 about the logic of thinking of terrorists. Through that theory, Crenshaw explained that terrorism is an act that 
expresses political strategy. Terrorism is also an action based on a certain logical process so that it can be studied and explained. By referring to the origin of terrorist behavior, terrorism is a solid choice made by a terrorist organization or group with strategic and political reasons, not an action that is influenced by social and psychological factors (Reich, ed., 1998, p. 7).

In terms of an analytical approach, terrorism is considered as an illustration of a collective rationality. A radical political organization is seen as the main actor in the drama of terrorism. The organization has collective preferences and decides terrorism as the main choice of various other alternative actions. Crenshaw stated that the decision-making process in a terrorist group was carried out by looking at the effectiveness of the actions to be taken. The terrorist group will compare the action with various strategy choices based on observation and experience. Crenshaw also saw the possibility of joining individuals in a rational group so as to bring about collective rationality (Reich, ed., 1998, p. 8-9).

In fact, terrorist groups can make mistakes when making decisions. However, not all of them occur due to miscalculation. Therefore, it is necessary to see the level of limited rationality. The Rational Choice Theory can be used to answer important questions about the choice or ultimate goal of a terrorist group. All decisions taken by terrorists or terrorist groups have gone through a rational process with strategic considerations. This strategic consideration is obtained by calculating the advantages and disadvantages of the actions to be taken. The decision making by terrorists includes strategies for planning, training, carrying out attacks and funding (Reich, ed., 1998, p. 9-24).

\section{Results}

At the beginning, the source of funding for the Mujahidin Indonesia Timur (MIT) or the Santoso Group came from personal contributions from its members or known as infak. The source of the funds became a mainstay when they started in the Gunung Biru area, Tamanjeka, Poso Pesisir, in 2011. The members of the Santoso Group provided infak from their business profit in plantation sector especially cocoa plantation. The infak was used as the initial capital of the Santoso Group and brought in cash to the top of the mountain. If the group members need additional logistics - such as rice, instant noodles, sugar, coffee or other food - to survive in the forest, some of them will go down the mountain to hand over money to other members in the city. Members in the city will buy the logistical needs and deliver them to the designated locations (Interview with Gunawan Djuraedjo, 2018).

Later, the Santoso Group had other sources of funds because infak unreliable to support their activities for a long term. Santoso Group then committed a criminal act in the form of motorcycle theft or known as $f^{\prime} i$. Badan Nasional Penanggulangan Terorisme/National Counter Terrorism Agency (BNPT) noted that motorcycle theft was carried out by Santoso Group members in the Poso region, Central Sulawesi, since 2011. The theft of motorbikes was also considered as a source of initial funding for the Santoso Group (Interview with a member of the BNPT Terrorism Funding Control Team, 2018). However, a former member of the Santoso Group, Muhammad Fadli Gani Ibrahim aka Rodik aka Mamat, said that motorbike theft had only begun since 2013. Fadli was one of the people in charge of the theft.

Motorcycle theft is not only carried out in Poso City but covers the entire area of Poso Regency. The theft was carried out by members of the Santoso Group who were in Poso Kota or did not join the Gunung Biru. They sell stolen motorbikes without an official letter or illegaly to a number of villages in Poso District at the price of IDR 3-4 million per motorcycle. Twenty 
percent of the sales money were handed over in cash to finance the activities of the Santoso Group, while the remainder was divided evenly for members who committed theft. Motorcycle theft lasted until 2014 when those who usually committed crimes were arrested by police (Interview with Muhammad Fadli Gani Ibrahim, 2018).

Besides infak dan $f a^{\prime} i$, the Santoso Group also has other sources of funds, namely personal donations or donations from sympathizers or network groups. Sympathizers or networks of groups that often make contributions come from a number of regions in Indonesia, especially Bima in West Nusa Tenggara, Kalimantan, and Java (Interview with Gunawan Djuraedjo, 2018). BNPT noted that donations from sympathizers were the main capital of Santoso Group because most of the group's funding sources came from there (BNPT White Paper, 2017, p. 10). In fact, total value of donations from sympathizers reach hundreds of millions of rupiah (Interview with a member of the BNPT Terrorism Funding Control Team, 2018).

Santoso Group began using donations from sympathizers as a source of their funds since 2012. They did not form a special structure in charge of searching, collecting, and managing donations from sympathizers. The method used is very simple, namely by asking some of their members in Poso Kota or those who did not join the Gunung Biru to carry out the task. At first, the task was carried out by Hendro aka Ande and Nudin. They will start looking for and collecting donations if there is a message from Gunung Biru which asks for additional funds to buy a number of needs (Interview with Gunawan Djuraedjo, 2018).

To Hendro and Nudin, the message was sent by a member of the Santoso Group in Gunung Biru--occasionally the message carried out directly by Santoso and Daeng Koro--via e-mail or Facebook Messenger using a cellphone. Hendro and Nudin then communicated with a number of Santoso Group sympathizers or networks in a number of parts of Indonesia to deliver messages about the funding needs. Usually they communicate via e-mail or Facebook Messenger. Communication via SMS (short message service) is rarely used. Telephone contact was also never used (Interview with Gunawan Djuraedjo, 2018). For Santoso Group, communication via SMS and telephone is considered insecure because it is vulnerable to being tapped or known by the police.

The communication was responded by a number of sympathizers or the Santoso Group network in several parts of Indonesia by sending donations. The fund support is inseparable from the wish of sympathizers to revive the "jihad" struggle in Poso to establish an Islamic state. Most sympathizers who donate funds actually do not know Santoso directly, but they have the same view of the desire to form an Islamic state. When the Santoso Group declared its allegiance to the Islamic State of Iraq and Syria (ISIS) in 2014, that view also changed, namely to make Poso as one of the ISIS bases in Southeast Asia, in addition to the South Philippines (Interview with a member of Densus 88, 2018).

Donations from sympathizers were sent via bank transfer to Hendro's account. After that, Hendro usually asked Nudin to withdraw the funds at the ATM machine, then Nudin handed them in cash to Gunawan Djuraedjo to buy some of the Santoso Group's needs in Gunung Biru. Some funds in cash are also sometimes bring in to the mountain as "savings". The handover of funds as "savings" is usually at the request of those who are in Gunung Biru. The money value is IDR 2-3 million each time (Interview with Gunawan Djuraedjo, 2018).

Hendro and Nudin only carried out the task until the beginning of 2014 because the two were shot dead during a raid by Densus 88 in Poso Pesisir. Even so, the Santoso Group funding sources from sympathizer donations did not necessarily die. The search and collection of donations from sympathizers was continued by other members of the Santoso Group in Poso Kota. With funding patterns that are the same as those of Hendro and Nudin, the search and collection of donations continued as Santoso Group declared allegiance to ISIS. 
Hasan aka Abu Yazid aka Hasan Ayam was one of the members of the Santoso Group who continued the work of Hendro and Nudin as searchers, collectors and managers of donations from sympathizers. To find and collect donations, Hasan communicated with a number of Santoso Group sympathizers, especially sympathizers from Bima, West Nusa Tenggara (Interview with Gunawan Djuraedjo, 2018). Based on the Republic of Indonesia's Supreme Court's decision on one of the members of the Santoso Group, Ramadhan Ulhaq alias Deni (decision No. 775/Pid.Sus/2015/PN.JktTim), donations from the sympathizers were collected by Hasan in his wife bank account, Rosmawati aka Ros aka Umi Yazid. Total donations transferred by sympathizers to Rosmawati's account reached IDR 20 million. Details of the donations: IDR 9 million transferred in December 2014, IDR 2 million at the end of December 2014, and IDR 9 million in January 2015 (p. 23-24).

The funds are then disbursed through an ATM machine by Rosmawati or sometimes by Hasan himself. Then they spend it to buy a number of Santoso's needs. After that, they left the shopping items in a place and asked other people to pick them up and then deliver to Santoso Group in Gunung Biru. Some of the funds were also given in cash to the mountain, which is worth IDR 7 million, as "savings". The request for cash was the mandate of a member of the Santoso Group, Mukhtar, which was conveyed to Hasan through Telegram using a cellphone (p. 23-27).

Besides Hasan and Rosmawati, Hendro Fernando also searched and collected donations from sympathizers. Hendro is a Santoso Group network that resides in Bekasi, West Java (BNPT White Paper, 2017, p. 10). Like Hasan and Rosmawati, Hendro also sought and collected donations from sympathizers in a number of Indonesian regions, especially sympathizers from Bima, West Nusa Tenggara. Based on BNPT records, the donation was collected by Hendro in his bank account, then he transferred to Rosmawati's account so that it could be disbursed and used to buy a number of Santoso's needs (Interview with a member of the BNPT Terrorism Funding Control Team, 2018).

The Santoso Group used donations from sympathizers for three needs: buying logistics in the form of clothing, food, medicine, and various other equipment that would be used in Gunung Biru; buy weapons; and distributed to the wives of group members who have died or been caught by the police (BNPT White Paper, 2017, p. 10-11). When Hendro and Nudin took care of funding, the logistics often purchased included rice, cooking oil, instant noodles, salted fish and tarpaulin material. Every time they shop, the value reaches IDR 1-2 million (Interview with Gunawan Djuraedjo, 2018). As for a portion of the total IDR 20 million in funds contributed by sympathizers entering Rosmawati's account, among others, was used to buy logistics in the form of rice, salted fish, tarpaulin material and outdoor shoes (Supreme Court ruling No. 775/Pid.Sus/2015/PN.JktTim, 2015, p. 24).

For weapons, the Santoso Group usually buys directly from sellers of illegal weapons located in Sulawesi, especially in Makassar, South Sulawesi (Interview with Gunawan Djuraedjo, 2018). In addition, they also bought weapons from the South Philippines (BNPT White Paper, 2017, p. 11). The method used by the Santoso Group was to send one of their members to go to the Southern Philippines with an allowance worth IDR 2 million. The member then met the person who became the liaison to the weapons seller there. It was not difficult for the Santoso group to buy weapons there because some members of the group had joined the Abu Sayyaf group in the southern Philippines (Interview with a member of the BNPT Terrorism Funding Control Team, 2018).

The funds distributed to the wives of members of the group who have died or caught by the police are intended to support their daily lives. The fund is not routinely distributed every month but depends on the situation. If there are donations from sympathizers, the wives will get 
a share. If there are no donations, there will be no funds flowing to the wives (Interview with Gunawan Djuraedjo, 2018). When Hasan and Rosmawati took care of funding, they recorded three times sending money to the wives of Santoso Group members who had died or were caught by the police, worth IDR 2 million, IDR 7 million and IDR 2 million respectively (Supreme Court ruling No. 775/Pid.Sus/2015/PN.JktTim, 2015, p. 23). BNPT noted that the funds must have been channeled to the wives (Interview with a member of the BNPT Terrorism Funding Control Team, 2018).

Referring to the Financial Action Task Force (2015) report and the identification of the Indonesian National Risk Assessment Team (2015), Santoso's funding sources fall into two categories. First category is personal donations or donations from sympathizers or group networks--including personal contributions from members who known as infak. Second category is the results of criminal acts in the form of motorcycle theft. The funds are transferred in a way that is still classified as "traditional", namely through cash transfers and bank transfers-including electronic systems using ATM cards. Funding sources and transfer of funds then form a funding pattern that involves four parties: funders, fund collectors, fund transfers, and fund users.

The Santoso Group's funding pattern in searching, collecting and managing donations from sympathizers illustrates the expression of a terrorist political strategy as expressed by Martha Crenshaw through the Rational Choice Theory. Santoso Group used the funding pattern because it was the result of the logical thinking process in their group which was then chosen and used. Before deciding to use the funding pattern, Santoso Group would have reviewed its effectiveness to support their activities. Effectiveness is measured by their observations and experience during applying other funding patterns for their two sources of funds, namely personal contributions from members or infak and committing criminal acts in the form of motorcycle theft or $f a^{\prime} i$.

The funding patterns used in searching, collecting, and managing donations from investigators have three advantages compared to funding patterns in collecting member infak and motorcycle theft, which are easier, safer, and generate more funds. The superiority of the funding pattern is inseparable from the strategy of assigning several group members to find, collect, and manage donations. In carrying out these tasks, they also strategize by choosing communications that are considered easier and safer, namely through e-mail and a number of social medias such as Facebook Messenger and Telegram. Thus, the funding pattern applied by the Santoso Group in searching, collecting, and managing donations from sympathizers is a decision taken by the group through a rational process with strategic considerations by calculating the advantages and disadvantages of applying the funding pattern.

If it is associated with Freeman's Study (2012), the Santoso Group funding method has at least fulfilled four of the six criteria. The criterias are quantity, security, control, and simplicity. In terms of quantity, the Santoso Group considers donations from sympathizers to be the source of funds that generate the greatest amount of money. For security criteria, the group assesses donations as the safest and most sustainable source of funds. The control relates to time and speed when obtaining donations to support the group. While simplicity is illustrated by the ease of the Santoso Group in seeking and raising funds through donations from sympathizers. 


\section{Conclusion}

Since its establishment in 2011, the Mujahidin Indonesia Timur (MIT) or the Santoso Group have three sources of funds used for their various activities: personal donations from members or infak, donations from sympathizers or group networks, and the result of committing a criminal act in the form of motorcycle theft. The money used from the source of funds includes bank transfers, including electronic ATM cards.

The personal contribution of members or infak is initial funding source for the Santoso Group. Members give infak from the business profit in plantation sector especially cocoa plantation. Because it was not reliable for the long term, Santoso Group then sought other sources of funds by conducted criminal acts in the form of motorcycle theft or known as fa'i. However, the source of the funds could only support the Santoso Group until 2014. The reason was that a number of members who often stole motorbikes were arrested by the police so that no one else could commit the crime.

Personal donations or donations from sympathizers or group networks are the main source of funds for Santoso Group. Santoso has used the source of funds since 2012 and continues when they have declared allegiance to ISIS. Sympathizers or networks of groups that often make contributions come from a number of regions in Indonesia, especially Bima in West Nusa Tenggara, Kalimantan, and Java. Overall, donations from the group's sympathizers reached hundreds of million rupiah.

The Santoso Group does not form a special structure in charge of searching, collecting, and managing donations from sympathizers. The method used is very simple, namely by asking some of their members in Poso Kota or those who do not go to Gunung Biru to carry out the task. Some members use communication strategies through e-mail and a number of social medias such as Facebook Messenger and Telegram, to search, collect, and manage donations from sympathizers. The task they run is to form a funding pattern that involves four parties: funders, fund collectors, fund transfers, and fund users.

Referring to the Rational Choice Theory by Martha Crenshaw, the funding pattern of the Santoso Group in searching, collecting, and managing donations from sympathizers illustrates an expression of a terrorist political strategy. Santoso Group uses the funding pattern because three advantages: easier, safer, and generate more funds. The funding pattern used by the Santoso Group in searching, collecting, and managing donations from sympathizers is a decision taken by the group through a rational process with strategic considerations by calculating the advantages and disadvantages of applying the funding pattern.

\section{References}

[1] Badan Nasional Penanggulangan Terorisme. (2017). Pemetaan Risiko Tindak Pidana Pendanaan Terorisme terkait Jaringan Teroris Domestik yang Terafiliasi dengan Islamic State of Iraq and Syria (ISIS). White Paper BNPT 2017, pp. 1-28.

[2] Balasubramanniyan, V. (2015). Understanding the Costing Decisions Behind Terror AttacksAn Analytical Study. Journal of Money Laundering Control, Vol. 18, No. 4, pp. 475- 487.

[3] Document of the Republic of Indonesia's Supreme Court's decision on one of member of the Santoso Group, namely Ramadhan Ulhaq aka Deni (Decision Number 775/Pid.Sus/2015/PN.JktTim).

[4] Financial Action Task Force. (2015). Emerging Terrorist Financing Risks. Paris: Financial Action Task Force. 
[5] Hamin, Z., et. al. (2016). Conceptualizing Terrorist Financing in The Age of Uncertainty. Journal of Money Laundering Control, Vol. 19, No. 4, pp. 397-406.

[6] Indonesian National Risk Assessment Team. (2015). Penilaian Risiko Indonesia terhadap Tindak Pidana Pendanaan Terorisme Tahun 2015. Jakarta: Pusat Pelaporan dan Analisis Transaksi Keuangan (PPATK).

[7] Interview with former Santoso Group member, Gunawan Djuraedjo aka Gugun aka Agus aka Ninja, in Poso Kota and Tentena, Poso District, Central Sulawesi, on WednesdayThursday, August 29-30, 2018.

[8] Interview with former Santoso Group member, Muhammad Fadli Gani Ibrahim aka Rodik aka Mamat, in Poso Kota and Tentena, Poso District, Central Sulawesi, on Wednesday-

Thursday, August 29-30, 2018.

[9] Interview with a member of the BNPT Terrorism Funding Control Team, in Serpong, South Tangerang, Banten, on Monday, July 16, 2018.

[10] Interview with a member of Detasemen Khusus 88 Antiteror Kepolisian RI (Densus 88/Detachment 88), in Jakarta, on Thursday, August 2, 2018.

[11] Institute for Policy Analysis of Conflict. (2014). The Evolution of ISIS in Indonesia. IPAC Report, No. 13, 24 September 2014, pp. 1-25.

[12] Jones, S. and Solahudin. (2014). Terrorism in Indonesia, A Fading Threat?. Southeast Asian Affairs, Singapore, pp. 139-147.

[13] Jones, S. and Solahudin. (2015). ISIS in Indonesia. Southeast Asian Affairs, Singapore, pp. 154-163.

[14] Law Number 9 of 2013 about Prevention and Eradication of Crime in the Financing of Terrorism.

[15] Mbai, Ansyaad. (2014). Dinamika Baru Jejaring Teror di Indonesia. Jakarta: Penerbit AS Production Indonesia.

[16] Reich, W. (ed.). (1998). Origins of Terrorism: Psychologies, Ideologies, Theologies, States of Mind. Washington: Woodrow Wilson Center Press. 
